\title{
THE EFFECT OF TIGECYCLINE ON THE BINDING OF FLUOROQUINOLONES TO HUMAN SERUM ALBUMIN
}

Ratomir M. Jelic ${ }^{1}$, Stefan D. Stojanovic ${ }^{1}$, Jelena D. Beric ${ }^{1}$, Jadranka Odovic ${ }^{2}$

${ }^{1}$ Faculty of Medical Science, University of Kragujevac, Serbia

${ }^{2}$ Faculty of Pharmacy, University of Belgrade, Serbia

\author{
DEJSTVO TIGECIKLINA NA VEZIVANJE FLUOROHINOLONA \\ ZA HUMANI SERUMSKI ALBUMIN \\ Ratomir M. Jelić ${ }^{1}$, Stefan D. Stojanović1 ${ }^{1}$ Jelena D. Berić ${ }^{1}$, Jadranka Odović ${ }^{2}$ \\ ${ }^{1}$ Fakultet medicinskih nauka, Univerzitet u Kragujevcu, Srbija \\ ${ }^{2}$ Farmaceutski fakultet, Univerzitet u Beogradu, Srbija
}

\begin{abstract}
The co-administration of several drugs in multidrug therapy may alter the binding of each drug to human serum albumin (HSA) and, thus, their pharmacology effect. Therefore, in this study, the interaction mechanism between HSA and two fluoroquinolones (FQs), sparfloxacin (SPF) and levofloxacin (LVF), was investigated using fluorescence and absorption methods in the absence and presence of the competing drugtigecycline (TGC). The the UV-Vis and fluorescence spectroscopy results showed that the fluorescence quenching of HSA was a result of the formation of the HSA-SPF and HSA-LVF complexes. The fluorescence quenching of HSA-TGC revealed that tigecycline can regulate the binding sites, binding mode and binding affinity of fluoroquinolones. The binding constants $\left(K_{A}\right)$ and binding sites $(n)$ of the interaction systems were calculated. The results confirmed that the $K_{A}$ values of the HSA-FQ system decreased in the presence of TGC, indicating that TGC can affect the binding ability of FQ for HSA. This interaction may increase the free plasma concentration of unbound FQ and enhance their pharmacology effect.
\end{abstract}

Keywords: Fluorescence, Human serum albumin, Fluoroquinolones, Tigecycline.

\section{SAŽETAK}

Istovremena primena nekoliko lekova, u multilek terapiji, može izmeniti njihovo vezivanje za humani serumski albumin (HSA) i njihov farmakološki efekat. Zbog toga, u ovom radu je proučavan mehanizam interakcije izmedu HSA $i$ dva fluorohinolona (FQs): sparfloksacina (SPF) i levofloksacina (LVF) fluorescentnim i apsorpcionim metodama u odsustvu i prisustvu konkurentskog leka - tigeciklina (TGC). Rezultati UV-Vis i fluorescentne spektroskopije su pokazali da je gašenje fluorescencije u HSA rezultat formiranja HSA-SPF i HSA-LVF kompleksa. Gašenje fluoroscencije u HSA-TGC je pokazalo da tigeciklin može regulisati mesta vezivanja, način vezivanja $i$ afinitet vezivanja fluorohinolona. Konstante vezivanja $\left(K_{A}\right)$ i broj vezujićih mesta $(n) z a$ interakcije u sistemu su izračunate. Rezultati su potvrdili da su vrednosti $K_{A}$ u HSA-FQ sistemu, smanjene u prisustvu TGC, a to ukazuje da TGC može da utiče na sposobnost vezivanja FQ za HSA. Ova interakcija može povećati slobodanu koncentraciju u plazmi nevezanog FQ $i$ poboljšati njegov farmakološki efekat.

Keywords: Fluorescencija, Humani serumski albumin, Fluorohinoloni, Tigeciklin.

\section{INTRODUCTION}

Human serum albumin (HSA) presents the most abundant serum protein in human plasma. HSA plays an important role in controlling distribution, excretion, therapeutic efficacy and drug toxicity in the human body (1-3). HSA possesses several low- and high-affinity ligand binding sites that have been identified as site I and site II. Each domain can be subdivided into subdomains A and B and is responsible for the binding of most drugs with the HSA $(4,5)$.

Whenever co-administration of several drugs is needed, their competition for the same binding site or confor-

mational changes in protein may occur. This leads to the increased or decreased concentration of the free drug fraction, which results in an enhanced or reduced therapeutic efficacy of the drug. Fluoroquinolones (FQs) belong to a group of antibacterial agents. Their mechanism of action consists of inhibiting different kinds of enzymes, such as homologous type 2, topoisomerase, DNA gyrase and DNA topoisomerase 4 , which play a crucial role in chromosome function and replication (6). Fluoroquinolones have a wide range of use. Their application has been reported in an em- 
<smiles>C=C(O)c1cn2c3c(c(N4CCN(C)CC4)c(F)cc3c1=O)OC[C@@H](C)N2c1c(F)c(N)c2c(=O)c(C(=O)O)cn(C3CC3)c2c1F</smiles><smiles>CN(C)c1cc(NC(=O)CNC(C)(C)C)c(O)c2c1C[C@H]1C[C@H]3[C@H](N(C)C)C(O)=C(C(N)=O)C(=O)[C@]3(O)C(O)=C1C2=O</smiles>

Fig. 1. Chemical structures of sparfloxacin (A), levofloxacin (B) and tigecycline (C).

pirical treatment of a variety of infections, especially in the genitourinary, gastrointestinal and respiratory tracts. Tigecycline possesses a similar mechanism of action to tetracyclines and acts by binding to the bacterial $30 \mathrm{~S}$ ribosomal subunit and inhibiting protein synthesis $(7,8)$. Tigecycline has been approved for treating complicated intra-abdominal infections as well as skin and skin structure infections (9). The chemical structures of the investigated drugs are shown in Fig. 1.

Spectral methods can reveal the binding of drugs with albumin at low concentrations. The fluorescence quenching technique is often used to monitor molecular interactions because of its high sensitivity, reproducibility and relatively easy use $(10,11)$. In the present study, the interactions of sparfloxacin and levofloxacin with HSA and the effect of tigecycline on these interactions by UV-Vis and fluorescence spectroscopy were investigated. Additionally, the binding of TGC to HSA was determined in our previously published research (12).

\section{MATERIAL AND METHODS}

\section{Chemical and reagents.}

Human serum albumin (HSA, lyophilized powder, free fatty acid $\leq 0.007 \%$, purity $\geq 96 \%$, catalogue No. A1887), sparfloxacin (SPF, purity $\geq 98 \%$, catalogue No. 56968), levofloxacin (LVF, purity $\geq 98 \%$, catalogue No. 28266) and tigecycline (TGC, tigecycline hydrate, purity $\geq 98 \%$, catalogue No. PZ0021) were purchased from the Sigma-Aldrich Chemical Company (St. Louis, MO, USA). The stock so- lutions of HSA $(20 \mu \mathrm{mol} / \mathrm{L})$, SPF $(0.11 \mathrm{mmol} / \mathrm{L})$, LVF $(0.1$ $\mathrm{mmol} / \mathrm{L})$ and TGC $(85.38 \mu \mathrm{mol} / \mathrm{L})$ were prepared fresh in phosphate buffer ( $\mathrm{pH} 7.4 ; 0.1 \mathrm{~mol} / \mathrm{L}$ ) containing $0.15 \mathrm{~mol} / \mathrm{L}$ $\mathrm{NaCl}$, that which was selected to keep the $\mathrm{pH}$ value and maintain the ionic strength of the solution. All the above solutions were kept in the dark at $0-4^{\circ} \mathrm{C}$ in a refrigerator. The sample masses were accurately weighed on a microbalance (Sartorius, ME215S) with a resolution of $0.1 \mathrm{mg}$. $\mathrm{pH}$ measurements were performed with a Beckman F-72 $\mathrm{pH}$ meter. All reagents were of analytical reagent grade and used without further purification. Newly double-distilled water was used throughout the experiment.

\section{$U V$-Vis and fluorescence spectroscopy.}

The absorption spectra were recorded on a double beam Lambda 25 UV/Vis Spectrophotometer (PerkinElmer, USA) equipped with $1.0 \mathrm{~cm}$ quartz cells. Fluorescence spectra were recorded using a RF-1501 PC spectrofluorometer (Shimadzu, Japan) equipped with a $150 \mathrm{~W}$ Xenon lamp source, a 1.0-cm path-length quartz cell and a thermostatic cuvette holder. The excitation and emission bandwidths were both $10 \mathrm{~nm}$.

In each combination, the quenching of HSA fluorescence by fluoroquinolone (FQ) was studied in the absence and presence of the competing drug, tigecycline (TGC). In the first set of experiments, the binding of each drug to HSA was studied under the same experimental conditions. The concentration of HSA was fixed at $2.0 \mu \mathrm{mol} / \mathrm{L}$, and those of SPF and LVF were varied. In the second set of experiments, the binding of FQ to HSA was determined simultaneously with TGC. The concentrations of HSA and 
TGC were fixed at $2.0 \mu \mathrm{mol} / \mathrm{L}$, and the concentrations of SPF and LVF were varied. The same sets of samples were used to obtain the UV-Vis spectra. All measurements were performed at a temperature of $298 \mathrm{~K}$.

\section{RESULTS}

\section{Fluorescence studies.}

The intrinsic fluorescence of HSA when it is excited at $295 \mathrm{~nm}$ is due primarily to the presence of the two tryptophan residues: Trp-134 and Trp-212. Trp-212 is located within a hydrophobic binding pocket in the IIA sub-domain of the protein, and Trp-134 is located on the surface of the albumin molecule and is more exposed to the environment (13). Although the tyrosine residue can also contribute to fluorescence, it presents a very weak emission (14). An important characteristic of the intrinsic fluorescence of HSA is that it is very sensitive to its microenvironment; it would be quenched if there is even a small change in the local surroundings of HSA, such as the biomolecular binding, protein conformation and denaturation (15). All fluorescence emission spectra were recorded from 300 to $450 \mathrm{~nm}$, with excitation at $295 \mathrm{~nm}$. It was necessary to distinguish between the static fluorescence quenching mode (resulting from the formation of a ground state complex between the fluorophore and the quencher) and the dynamic quenching mode (resulting from a collision between the fluorophore and the quencher). To confirm the quenching mechanism, the fluorescence data were analyzed at $298 \mathrm{~K}$ using the well-known Stern-Volmer Eq. (1) (16):

$$
\frac{F_{0}}{F}=1+K_{\mathrm{q}} \tau_{0}[\mathrm{Q}]=1+K_{\mathrm{SV}}[\mathrm{Q}]
$$

where $F$ and $F_{0}$ are the fluorescence intensities of the protein in the presence and absence of the quencher, re- spectively. $K_{\mathrm{q}}$ is the quenching rate constant of the biomolecule, [Q] is the quencher concentration, $K_{\mathrm{SV}}$ is the SternVolmer constant and $\tau_{0}$ is the lifetime of the fluorophore in the absence of the quencher $\left[\tau_{0}\right.$ is approximately $\left.10^{-8} \mathrm{~s}\right]$. If the biomolecular quenching constants are larger than the limiting diffusion rate constant of the biomolecule [2.0 $\mathrm{x}$ $\left.10^{10} \mathrm{~L} \mathrm{M}^{-1} \mathrm{~s}^{-1}\right]$ (17), the quenching is initiated not by the dynamic collision, but by the protein complex.

For the static quenching process, when small molecules bind independently to a set of equivalent sites on a biomacromolecule, the equilibrium between the free and bound molecules could be represented by the well-known Eq. (2) (16-18):

$$
\log \frac{F_{0}-F}{F}=\log K_{\mathrm{A}}+n \log [\mathrm{Q}]
$$

where $K_{\mathrm{A}}$ is the binding constant or the apparent association constant for drug-protein interaction, $n$ is the number of binding sites per HSA molecule and [Q] is the concentration of quencher.

The quenching of the intrinsic fluorescence of HSA by sparfloxacin and levofloxacin was studied. The fluorescence spectra of HSA were recorded in the presence of increasing amounts of FQ (Fig. 2 and Fig. 3).

As shown in Fig. 2 and Fig. 3, the fluorescence intensity of HSA decreased regularly with increasing concentrations of FQ, but the emission maximum and shape of the peaks remained almost unchanged. This indicated that SPF and LVF could bind to HSA. Upon drug binding, the fluorescence spectra of HSA were accompanied by a shift in emission wavelength towards a lower wavelength (blueshift) in the case of SPF and towards a higher wavelength (redshift) in the case of LVF. These results are in accordance with the previous study (19). The blue/redshift in the emission wavelength $\left(\lambda_{\max }\right)$ suggests a change in the hydrophobicity of the microenvironment of the drug binding region $(20,21)$.

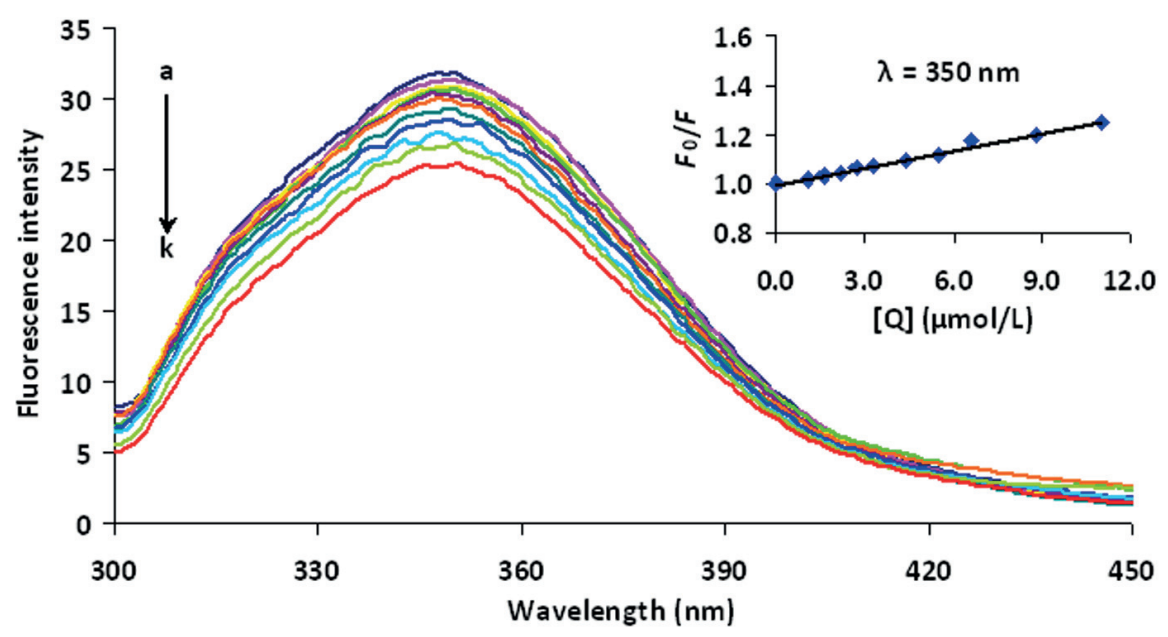

Fig. 2. The fluorescence quenching spectra of HSA by SPF $(T=298 \mathrm{~K}, \mathrm{pH}=7.4)$. [HSA] $=2.0 \mu \mathrm{mol} / \mathrm{L}$; [SPF] (a-k): $(0,1.1,1.65,2.2,2.75,3.3,4.4,5.5,6.6,8.8,11.0) \mu \mathrm{mol} / \mathrm{L}$. The lower insert shows Stern-Volmer plots of the fluorescence quenching of HSA by SPF. 


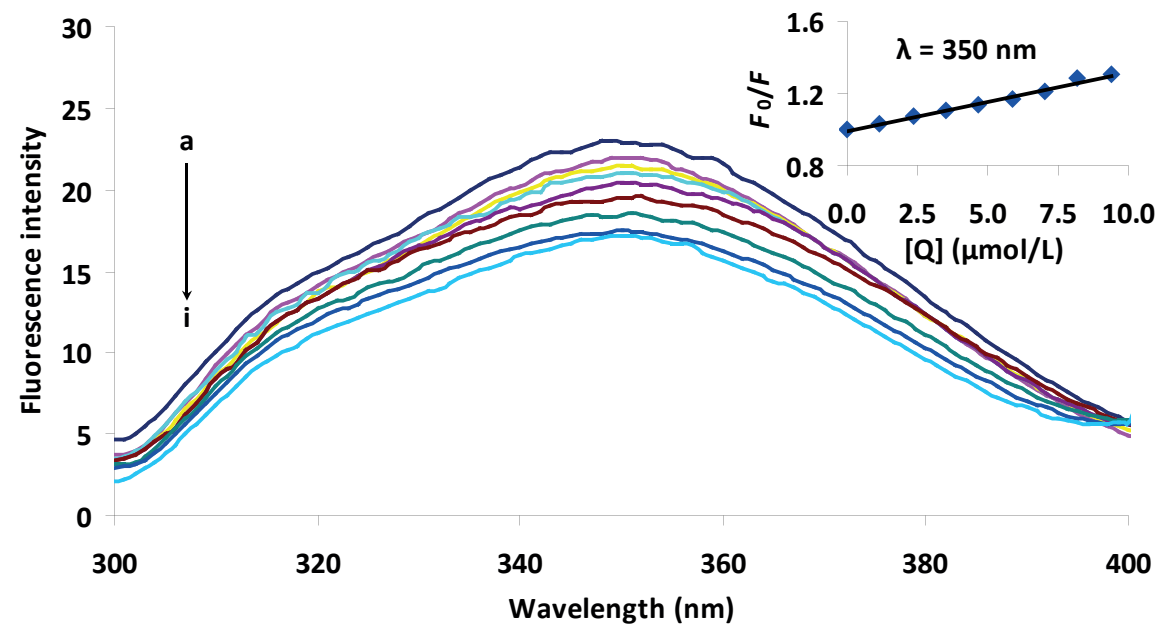

Fig. 3. The fluorescence quenching spectra of $\operatorname{HSA}$ by $\operatorname{LVF}(T=298 \mathrm{~K}, \mathrm{pH}=7.4)$. [HSA] $=2.0 \mu \mathrm{mol} / \mathrm{L}$; [LVF] (a-i): $(0,1.16,2.34,3.52,4.68,5.86,7.03,8.2,9.38) \mu \mathrm{mol} / \mathrm{L}$. The under insert is Stern-Volmer plots of the fluorescence quenching of HSA by LVF.

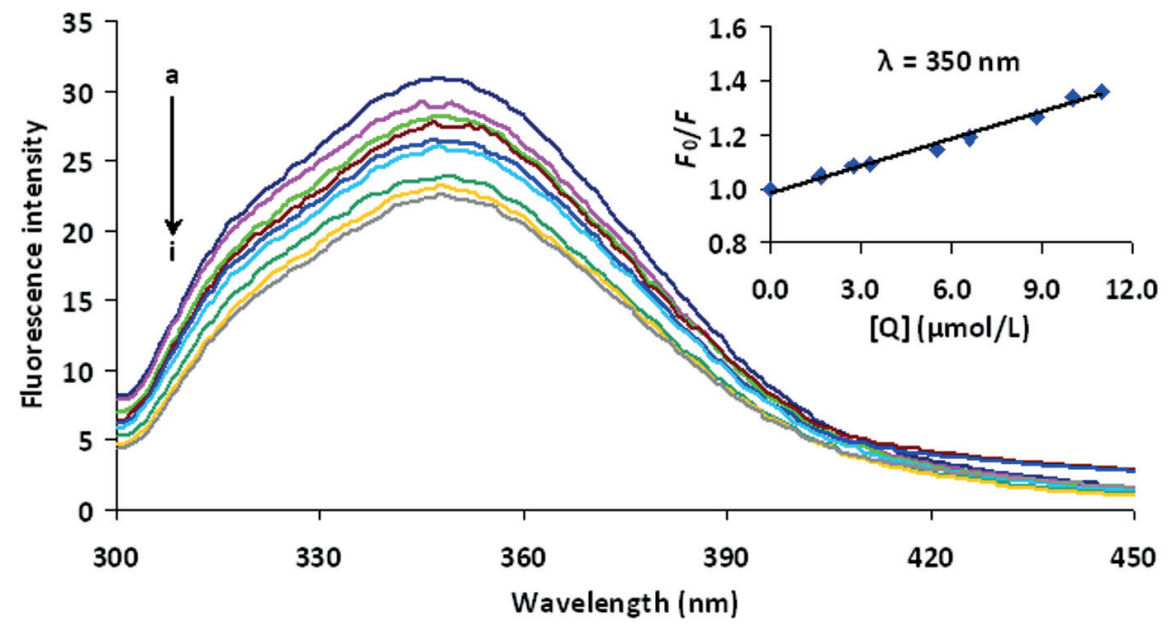

Fig. 4. The fluorescence quenching spectra of HSA by SPF in the presence of TGC ( $T=298 \mathrm{~K}, \mathrm{pH}=7.4)$ $[\mathrm{HSA}]=2.0 \mu \mathrm{mol} / \mathrm{L} ;[\mathrm{SPF}](\mathrm{a}-\mathrm{i}):(0,1.65,2.75,3.3,5.5,6.6,8.8,10.0,11.0) \mu \mathrm{mol} / \mathrm{L} ;[\mathrm{TGC}]=2.0 \mu \mathrm{mol} / \mathrm{L}$ The lower insert shows Stern-Volmer plots of the fluorescence quenching of HSA by SPF in the presence of fixed TGC concentration.

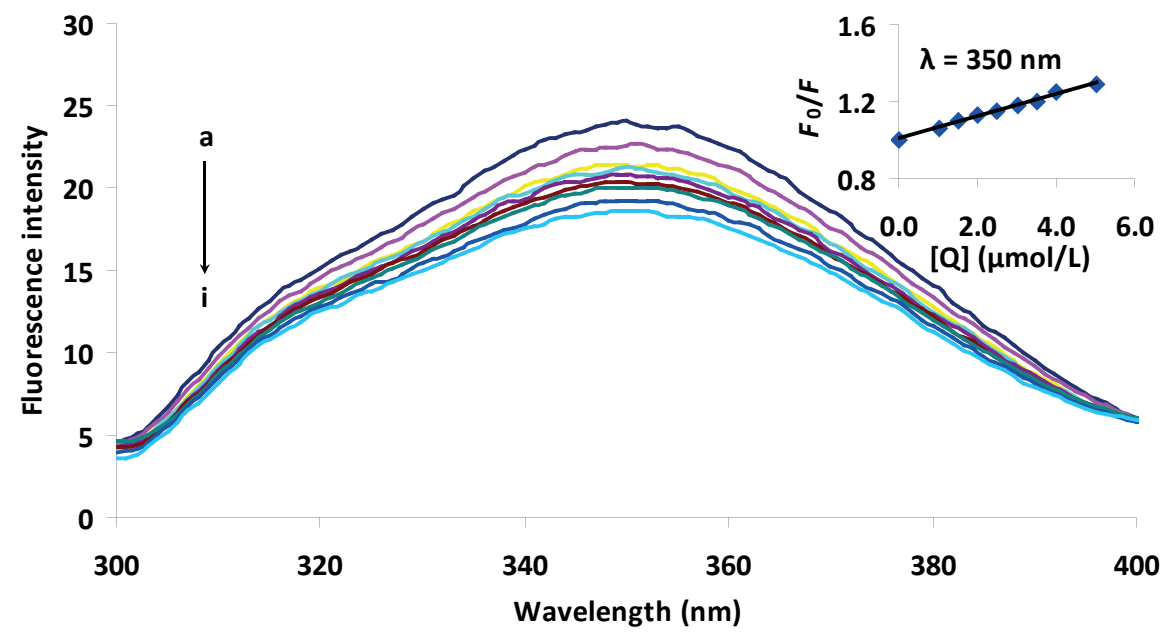

Fig. 5. The fluorescence quenching spectra of HSA by LVF in the presence of TGC $(T=298 \mathrm{~K}, \mathrm{pH}=$ 7.4). $[\mathrm{HSA}]=2.0 \mu \mathrm{mol} / \mathrm{L} ;[\mathrm{LVF}](\mathrm{a}-\mathrm{i}):(0,1.0,1.5,2.0,2.5,3.0,3.5,4.0,5.0) \mu \mathrm{mol} / \mathrm{L} ;[\mathrm{TGC}]=2.0 \mu \mathrm{mol} / \mathrm{L}$ The under insert is Stern-Volmer plots of the fluorescence quenching of HSA by LVF in the presence of fixed TGC concentration. 


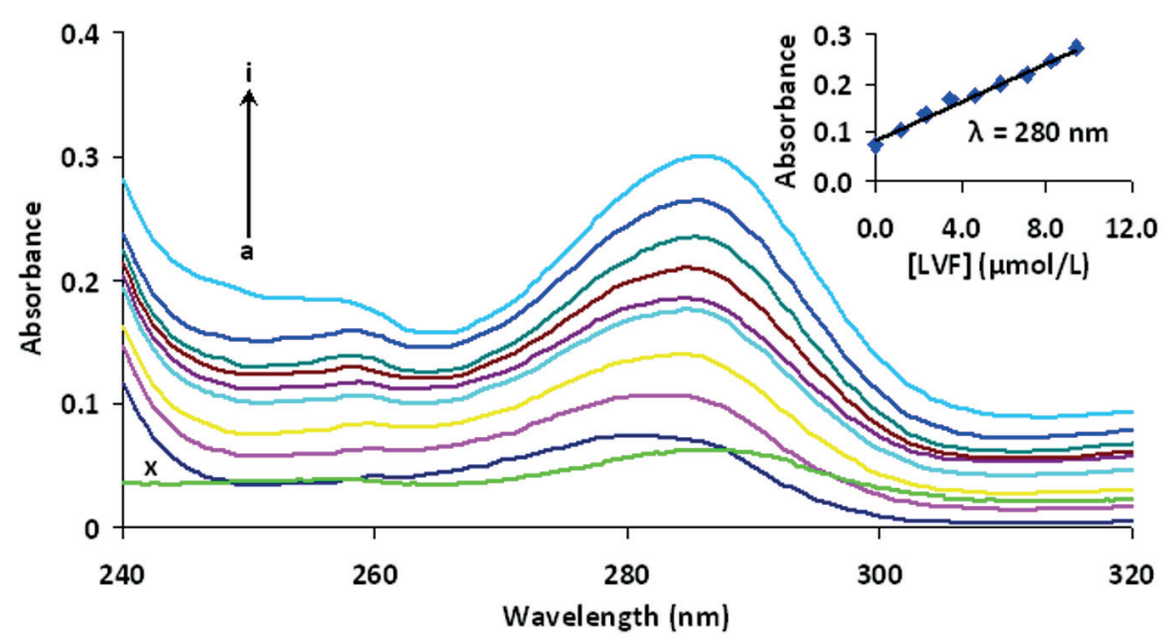

Fig. 6. Absorption spectra of HSA in the presence of various LVF concentrations ( $T=298 \mathrm{~K}, \mathrm{pH}=7.4)$. $[\mathrm{HSA}]=2.0 \mu \mathrm{mol} / \mathrm{L} ;[\mathrm{LVF}](\mathrm{a}-\mathrm{i}):(0,1.16,2.34,3.52,4.68,5.86,7.03,8.2,9.38) \mu \mathrm{mol} / \mathrm{L}$. x represents 2.0 $\mu \mathrm{mol} / \mathrm{L}$ LVF only.

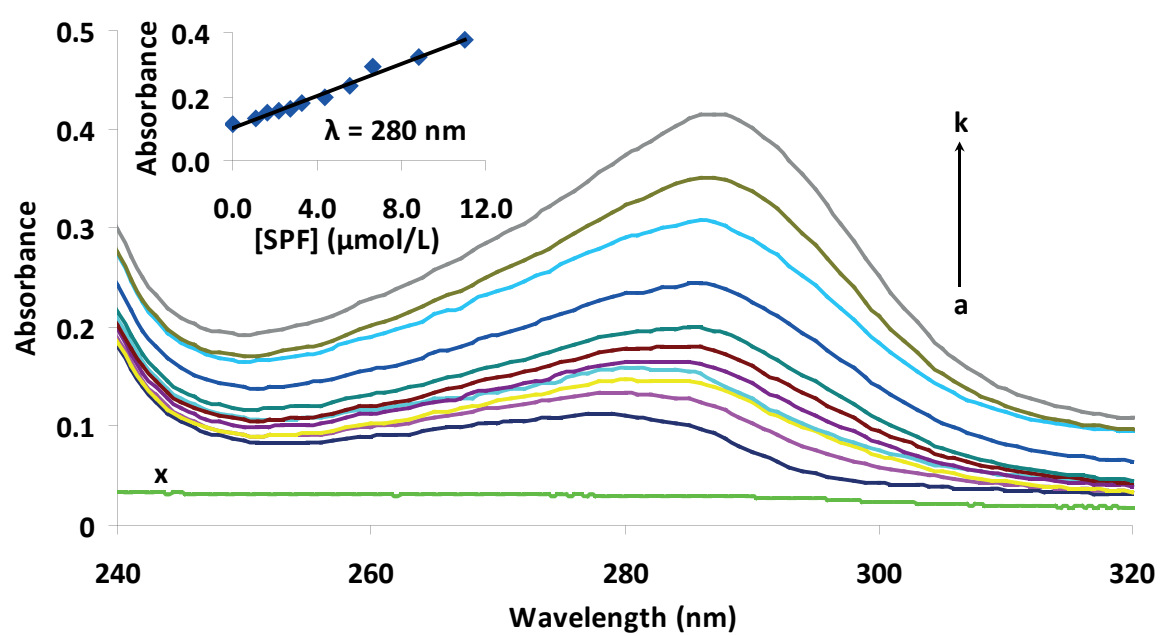

Fig. 7. Absorption spectra of HSA in the presence of various SPF concentrations $(T=298 \mathrm{~K}, \mathrm{pH}=$ 7.4). $[\mathrm{HSA}]=2.0 \mu \mathrm{mol} / \mathrm{L}$; $[\mathrm{SPF}](\mathrm{a}-\mathrm{k}):(0,1.10,1.65,2.2,2.75,3.3,4.4,5.5,6.6,8.8,11.0) \mu \mathrm{mol} / \mathrm{L} . \mathrm{x}$ represents $2.0 \mu \mathrm{mol} / \mathrm{L}$ SPF only.

Drug-drug interactions at the protein-binding level can be useful for therapeutic purposes because an alteration in protein binding may change the volume of distribution, clearance, and elimination of a drug and may modulate its therapeutic effect $(22,23)$. The binding affinity of FQs for HSA in the presence of TGC and the competitive binding mechanism were investigated. The fluorescence spectra of the HSA-TGC complex were recorded in the presence of an increasing amount of FQs (Fig. 4 and Fig. 5). Increasing the concentration of FQs led to an increased quenching fluorescence signal of the HSA-TGC complex (Fig. 4 and Fig. 5), suggesting that FQs interact with the HSA-TGC complex. Therefore, sparfloxacin and levofloxacin can displace TGC from its binding site, which means that TGC and these drugs may share some common binding sites in HSA.

\section{$U V$-Vis absorption studies.}

UV-Vis absorption measurement is a very simple method and can be used to explore the structural changes and determine complex formations $(15,24)$. HSA has a weak absorption peak at approximately $280 \mathrm{~nm}$ because of cumulative absorption of three aromatic amino acid residues (Trp, Tyr and Phe). The absorbance peak around $280 \mathrm{~nm}$ is raised, which is mainly caused by the $\pi-\pi *$ transition of aromatic amino acid residues in HSA $(25,26)$. In the present study, the changes in the UV-Vis absorption spectra of the HSA-LVF system (Fig. 6) and HSA-SPF (Fig. 7) were measured under the simulated physiological conditions. Additionally, the UV-Vis absorption spectra of the HSA-SPF and HSA-LVF system were measured in the presence of the fixed TGC concentration (Fig. 8 and Fig. 9). 


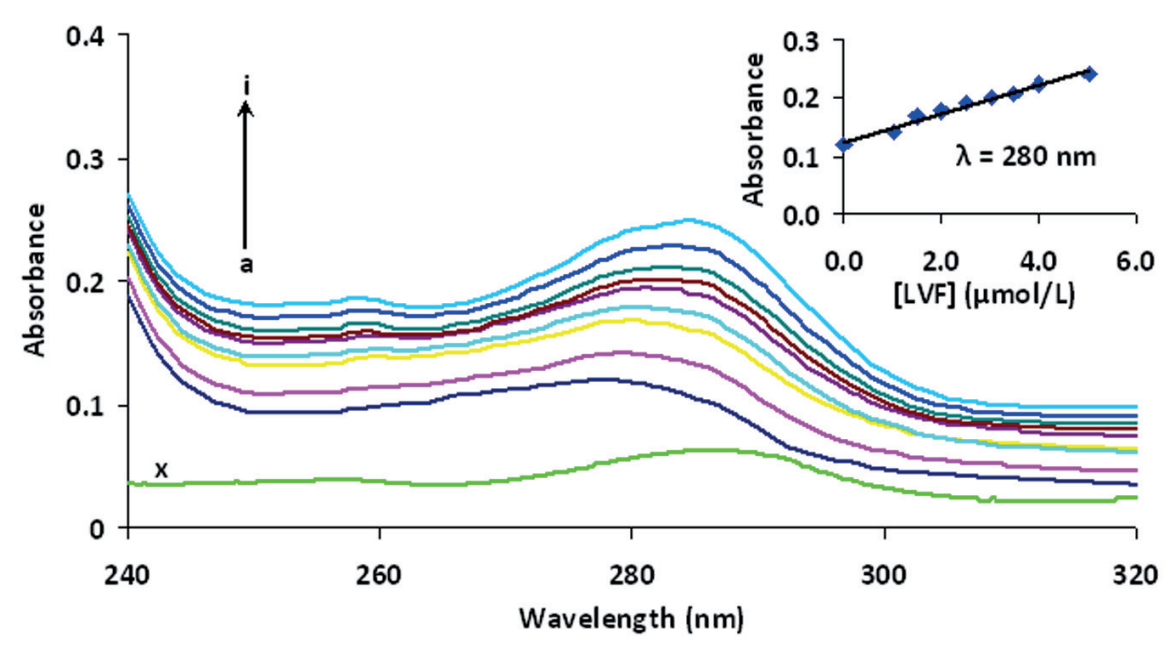

Fig. 8. Absorption spectra of HSA in the presence of various LVF concentrations and a fixed TGC concentration $(T=298 \mathrm{~K}, \mathrm{pH}=7.4)$. $[\mathrm{HSA}]=2.0 \mu \mathrm{mol} / \mathrm{L} ;[\mathrm{LVF}](\mathrm{a}-\mathrm{i}):(0,1.0,1.5,2.0,2.5,3.0,3.5,4.0,5.0)$ $\mu \mathrm{mol} / \mathrm{L} ;[\mathrm{TGC}]=2.0 \mu \mathrm{mol} / \mathrm{L} . \mathrm{x}$ represents $2.0 \mu \mathrm{mol} / \mathrm{L} \mathrm{LVF}$ only.

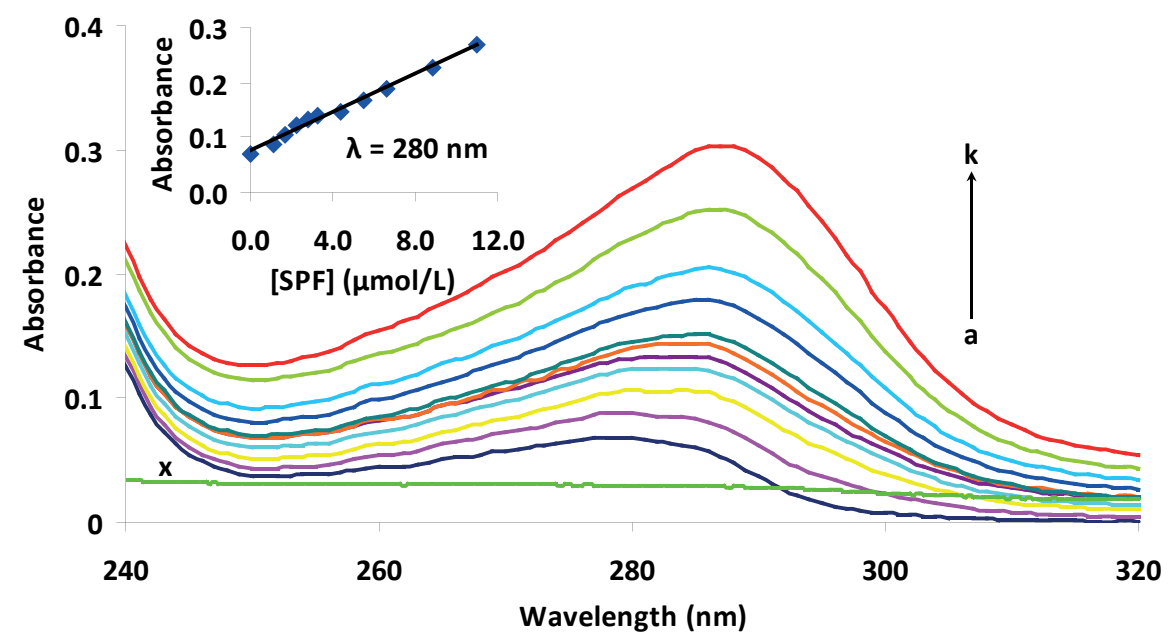

Fig. 9. Absorption spectra of HSA in the presence of various SPF and fixed TGC concentration (T $=298 \mathrm{~K}, \mathrm{pH}=7.4) .[\mathrm{HSA}]=2.0 \mu \mathrm{mol} / \mathrm{L} ;[\mathrm{SPF}](\mathrm{a}-\mathrm{k}):(0,1.1,1.65,2.2,2.75,3.3,4.4,5.5,6.6,8.8,11.0)$ $\mu \mathrm{mol} / \mathrm{L} ;[\mathrm{TGC}]=2.0 \mu \mathrm{mol} / \mathrm{L}$. $\mathrm{x}$ represents $2.0 \mu \mathrm{mol} / \mathrm{L}$ SPF only.

\section{DISCUSSION}

\section{Fluorescence and absorption spectra.}

The fluorescence intensity of HSA and HSA-TGC decreased regularly with increasing FQ concentrations (Figs. 2, 3, 4 and 5). The quenching mechanism was determined to investigate whether FQs interact with HSA and HSA-TGC to form a complex. To confirm the quenching mechanism, the fluorescence quenching data were analyzed according to the Stern-Volmer Eq. 1. Eq. 1 was applied to determine $K_{\mathrm{Sv}}$ via the linear regression of a plot of $F_{0} / F$ against [Q]. The $K_{\mathrm{Sv}}$ was then obtained from the slope. The values of $K_{\mathrm{SV}}$ and $K_{\mathrm{q}}$ were calculated and are given in Table 1 . Stern-Volmer plots for the fluorescence quenching of HSA and HSA-TGC by SPF and LVF are shown in the inserts in Figs. 2, 3, 4 and 5. The Stern-Volmer plots (Figs. 2, 3, 4 and 5) showed a linear curve for all of the investigated concentrations, which indicates that quenching type can be static or dynamic quench- ing because the characteristic Stern-Volmer plots of combined quenching (both static and dynamic) show an upward curvature (27). The linear plots, however, are insufficient to

Table 1. The quenching constants $\left(K_{\mathrm{q}}\right)$, binding constants $\left(K_{\mathrm{A}}\right)$ and number of binding sites $(n)$ of HSA-FQ systems in the absence and presence of TGC at $298 \mathrm{~K}$

\begin{tabular}{lccccc}
\hline System & $\begin{array}{c}\boldsymbol{K}_{\mathbf{q}} \\
\left(\mathbf{1 0}^{\mathbf{1 2}} \mathbf{L} / \mathbf{m o l} \cdot \mathbf{s}\right)\end{array}$ & $\boldsymbol{R}^{\mathbf{2}}$ & $\begin{array}{c}\boldsymbol{K}_{\mathrm{A}} \\
\left(\mathbf{1 0}^{4} \mathbf{L} / \mathbf{m o l}\right)\end{array}$ & $\boldsymbol{n}$ & $\boldsymbol{R}^{\mathbf{2}}$ \\
\hline HSA-TGC (12) & 4.99 & 0.996 & 1.76 & 0.91 & 0.991 \\
HSA-SPF & 2.35 & 0.990 & 10.75 & 1.13 & 0.991 \\
HSA-SPF-TGC & 3.32 & 0.987 & 7.56 & 1.08 & 0.990 \\
HSA-LVF & 3.31 & 0.986 & 9.24 & 1.09 & 0.992 \\
HSA-LVF-TGC & 5.87 & 0.995 & 2.74 & 0.94 & 0.995 \\
\hline
\end{tabular}




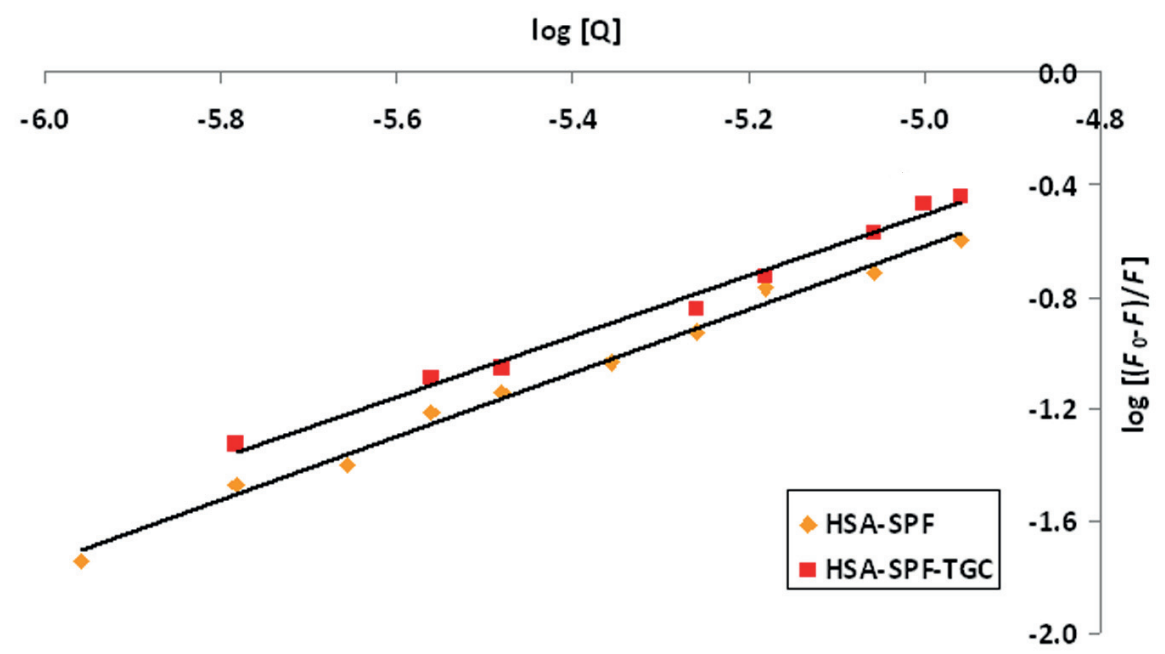

Fig. 10. Plots of $\log \left(F_{0}-F\right) / F$ versus $\log [Q]$ of HSA-SPF and HSA-SPF-TGC system at $298 \mathrm{~K}$.

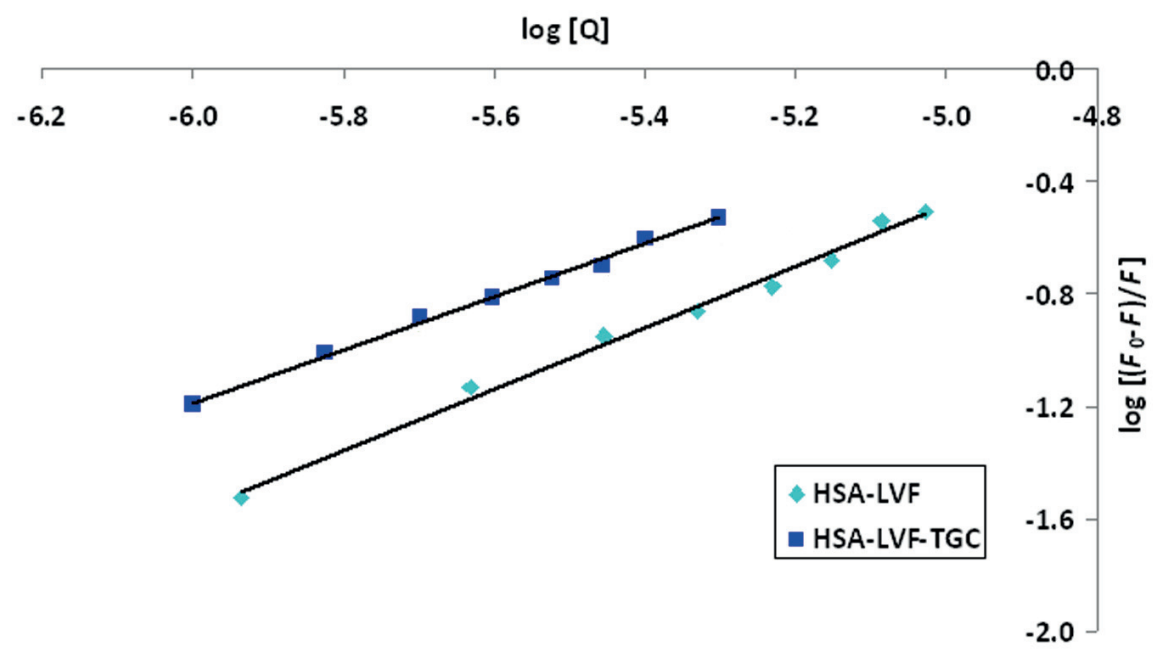

Fig. 11. Plots of $\log \left(F_{0}-F\right) / F$ versus $\log [\mathrm{Q}]$ of HSA-LVF and HSA-LVF-TGC system at $298 \mathrm{~K}$.

define the quenching type. Thus, based on previous works (28-31), the possible quenching mechanism between HSA and fluoroquinolones was suggested to be static quenching resulting from the complex formation instead of dynamic quenching. As evident from the results (Table 1), the $K_{\mathrm{q}}$ values $\left(>10^{12} \mathrm{~L} / \mathrm{mol} \cdot \mathrm{s}\right)$ are higher than those of diverse kinds of quenchers that are used for biopolymer fluorescence $(2.0 \times$ $\left.10^{10} \mathrm{~L} / \mathrm{mol} \cdot \mathrm{s}\right)$. These results indicate that the quenching was initiated not from a dynamic collision, but from the formation of a complex in all of the tested systems.

The absorption spectra of HSA and HSA-TGC at different concentrations of FQ (Figs. 6, 7, 8 and 9) showed that in the visible region, the absorbance values of HSA and HSA-TGC increased regularly with an increase in the concentration of FQ, suggesting that a complex was formed between FQs and HSA and between FQs and HSA-TGC (32). The absorption peaks of these solutions showed moderate shifts towards a longer wavelength, in- dicating that with the addition of FQ, the peptide strands of the HSA molecules extended farther and the hydrophobicity was changed (33).

\section{Binding parameters.}

The quenching mechanism was determined to be static quenching; thus, the binding constant $\left(K_{\mathrm{A}}\right)$ and the number of binding sites $(n)$ can be calculated according to Eq. 2 . The values of $K_{\mathrm{A}}$ and $n$ of all systems were obtained from the intercept and slope of the plots of $\log \left(F_{0}-F\right) / F$ versus $\log$ [Q] (Figs. 10 and 11).

The values of the binding constant $K_{\mathrm{A}}$ and of $n$ are given in Table 1 . The number of binding sites ( $\mathrm{n}$ ) is approximately 1 , indicating that there is one binding site in HSA for SPF and LVF. The binding constants of the HSA-SPF and HSA-LVF system that were found in this research are in agreement with previous studies $(34,35)$. The relatively high values of the stability constants suggest a strong interaction between 
HSA and the experimental drugs. Additionally, the binding constants of the HSA-FQ system in the presence of TGC were determined (Table 1). As seen from Table 1, both the binding modes and binding affinities of these drugs underwent changes. In the presence of TGC, the binding affinity of HSA for FQs decreased compared to those in the absence of TGC (Table 1). The decreased binding constants of fluoroquinolone in the presence of tigecycline imply both that fluoroquinolone and tigecycline share some common binding sites in HSA and that FQ cannot displace TGC from its binding sites on albumin. The specific sites for LVF and SPF on the protein molecule are already occupied by TGC, so FQs cannot completely displace TGC, which results in a decreased binding affinity of FQ to HSA in the presence of TGC (competitive interference). If the fluoroquinolones and tigecycline bind at different sites, the binding constants of the fluoroquinolones should remain unchanged. In such a case, the binding of FQ will not be affected by the presence of TGC (independent binding). The simultaneous binding of two drugs may also cause structural changes in the albumin molecule (non-competitive interference), thereby creating more binding sites or increasing the accessibility of the existing sites and hence increasing the degree of binding of the parent drug (34).

The degree of binding to albumin may have consequences for the rate of clearance of the metabolites and for their delivery to cells and tissues (36). Based on the conventional concept, the cellular uptake is proportional to the unbound fraction of drugs. According to this hypothesis (37), the distribution of FQ within the body is proportional to the free concentration of unbound FQ in circulating plasma. The reversible binding to blood proteins, such as serum albumin, may have consequences for the delivery of FQ and their metabolites to cells and tissues. If a molecule is highly bound to plasma proteins, the amount of drug that is available to diffuse into the target tissue may be significantly reduced, and the efficacy of the drug may consequently be poor. Here, it was found that TGC decreased the affinities of FQ for HSA. TGC in the blood will affect the transporting ability of serum albumin for $\mathrm{FQ}$, which may improve the free concentrations of unbound $F Q$ and enhance their pharmacological effects. These effects are significant in vivo.

\section{CONCLUSION}

In this study, the interaction of sparfloxacin and levofloxacin with HSA in the absence and presence of tigecycline was studied by spectroscopic methods, including fluorescence and UV-Vis absorption spectroscopy, under physiological conditions. The results showed that sparfloxacin and levofloxacin had a strong ability to quench the intrinsic fluorescence of HSA by creating the complexes through a static quenching mechanism. The binding constants $\left(K_{\mathrm{A}}\right)$ of the HSA-SPF and HSA-LVF systems were $10.75 \times 10^{4}$ and $9.24 \times 10^{4}$, respectively. The results illustrated that there is a strong binding force between HSA and the investigated drugs, and one molecule of drug binds to one molecule of
HSA with high affinity. The results confirmed that the binding constant $\left(K_{\mathrm{A}}\right)$ values of the HSA-FQ system decreased in the presence of TGC, indicating that TGC can affect the binding ability of FQ for HSA. This may increase the free plasma concentration of unbound FQ and enhance their pharmacological and toxicological effects. Studies on the interaction between plasma proteins and small moleculedrugs are thus an interesting field of future research.

\section{Acknowledgments}

This study was financed by research grant JP 08/16 given by the Faculty of Medical Sciences, University of Kragujevac and by research grant No. 172016 given by the Ministry of Education, Science and Technological Development of the Republic of Serbia.

\section{Conflict of Interest}

All of the authors declare no conflict of interest.

\section{REFERENCES}

1. Kragh-Hansen U, Chuang VT, Otagiri M. Practical aspects of the ligand-binding and enzymatic properties of human serum albumin. Biol Pharm Bull 2002; 25: 695-704.

2. Bertucci $C$, Domenici E. Reversible and covalent binding of drugs to human serum albumin: methodological approaches and physiological relevance. Curr Med Chem 2002; 9: 1463-1481.

3. Kandagal PB, Ashoka S, Seetharamappa J, Shaikh S, Jadegoud Y, Ijare OB. Study of the interaction of an anticancer drug with human and bovine serum albumin: spectroscopic approach. J Pharm Biomed Anal 2006; 41: 393-399.

4. Sudlow G, Birkett DJ, Wade DN. The characterization of two specific drug binding sites on human serum albumin. Mol Pharmacol 1975; 11: 824-832.

5. Sudlow G, Birkett DJ, Wade DN. Further characterization of specific drug binding sites on human serum albumin. Mol Pharmacol 1976; 12: 1052-1061.

6. Zhang LW, Wang K, Zhang XX. Study of the interactions between fluoroquinolones and human serum albumin by affinity capillary electrophoresis and fluorescence method. Anal Chim Acta 2007; 603: 101-110.

7. Zhanel GG, Homenuik K, Nichol K, et al. The glycylcyclines: a comparative review with the tetracyclines. Drugs 2004; 64: 63-88.

8. Fey G, Reiss M, Kersten H. Interaction of tetracylines with ribosomal subunits from Escherichia coli. A fluorometric investigation. Biochemistry 1973; 12: 1160-1164.

9. Townsend ML, Pound MW, Drew RH. Tigecycline in the treatment of complicated intra-abdominal and complicated skin and skin structure infections. Ther Clin Risk Manag 2007; 3: 1059-1070.

10. MacManus-Spencer LA, Tse ML, Hebert PC, Bischel HN, Luthy RG. Binding of perfluorocarboxylates to serum albumin: a comparison of analytical methods. Anal Chem 2010; 82: 974-981. 
11. Bi S, Song D, Tian Y, Zhou X, Liu Z, Zhang H. Molecular spectroscopic study on the interaction of tetracyclines with serum albumins. Spectrochim. Acta A Mol Biomol Spectrosc 2005; 61: 629-636.

12. Stojanović SD, Janković SM, Matović ZD, Jakovljević IŽ, Jelić R.M. Interaction between tigecycline and human serum albumin in aqueous solution. Monatsh Chem 2015; 146: 399-409.

13. Carter DC, Ho JX. Structure of serum albumin. Adv Protein Chem 1994; 45: 153-203.

14. Sudhamalla B, Gokara M, Ahalawat N, Amooru DG, Subramanyam R. Molecular dynamics simulation and binding studies of beta-sitosterol with human serum albumin and its biological relevance. J Phys Chem B, 2010; 114: 9054-9062.

15. Chen T, Cao H, Zhu S, et al. Investigation of the binding of Salvianolic acid B to human serum albumin and the effect of metal ions on the binding. Spectrochim. Acta A Mol Biomol Spectrosc 2011; 81: 645-652.

16. Lakowicz JR. Principles of Fluorescence Spectroscopy. 3rd ed, New York, Plenum Press, 2006.

17. Eftink M R. Fluorescence Quenching: Theory and Applications. Top Fluoresc Spectrosc 2002; 2: 53-126.

18. Zhang HM, Fei ZH, Tang BP, Chen J, Tao WH, Wang Y.Q. The interaction of blood proteins with brucine. Mol Biol Rep 2012; 39: 4937-4947.

19. Liu B, Zhao F, Xue C, Wang J, Lu Y. Studies on the antagonistic action between chloramphenicol and quinolones with presence of bovine serum albumin by fluorescence spectroscopy. J Lumin 2010; 130: 859-864.

20. Sandhya B, Hedge AH, Ramesh KC, Seetharamappa J. Exploring the binding mechanism of ondansetron hydrochloride to serum albumins: spectroscopic approach. Spectrochim Acta A Mol Biomol Spectrosc 2012; 86: 410-416.

21. Cao H, Liu Q. Effects of temperature and common ions on binding of puerarin to BSA. J Solution Chem 2009; 38: 1071-1077.

22. Otagiri M. A molecular functional study on the interactions of drugs with plasma proteins. Drug Metab Pharmacokinet 2005; 20: 309-323.

23. Tesseromatis C, Alevizou A. The role of the proteinbinding on the mode of drug action as well the interactions with other drugs. Eur J Drug Metab Pharmacokinet 2008; 33: 225-230.

24. Bi S, Song D, Tian Y, Zhou X, Liu Z, Zhang H. Molecular spectroscopic study on the interaction of tetracy- clines with serum albumins. Spectrochim. Acta A Mol Biomol Spectrosc 2005; 61: 629-636.

25. Peterson FC, Anderson PJ, Berliner LJ, Brooks CL. Expression, folding, and characterization of small proteins with increasing disulfide complexity by a pT7-7-derived phagemid. Protein Expr Purif 1999; 15: 16-23.

26. Wen MG, Zhang XB, Tian JN, et al. Binding interaction of xanthoxylin with bovine serum albumin. J Solution Chem 2009; 38: 391-401.

27. Wang N, Ye L, Zhao BQ, Yu JX. Spectroscopic studies on the interaction of efonidipine with bovine serum albumin. Braz J Med Biol Res 2008; 41: 589-595.

28. Seetharamappa J, Kamat BP. Study of the interaction between fluoroquinolones and bovine serum albumin. J Pharm Biomed Anal 2005; 39: 1046-1050.

29. Tarushi A, Polatoglou E, Kljun J, Turel I, Psomas G, Kessissoglou DP. Interaction of $\mathrm{Zn}(\mathrm{II})$ with quinolone drugs: structure and biological evaluation. Dalton Trans 2011; 40: 9461-9473.

30. Hu YJ, Yang YO, Bai AM, Li W, Liu Y. Investigation of the interaction between ofloxacin and bovine serum albumin: spectroscopic approach. J Solution Chem 2010; 39; 709-717.

31. Zivec P, Perdih F, Turel I, Giester G, Psomas G. Different types of copper complexes with the quinolone antimicrobial drugs ofloxacin and norfloxacin: structure, DNA- and albumin-binding. J Inorg Biochem 2012; 117: 35-47.

32. Donovan JW, Changes in ultraviolet absorption produced by alteration of protein conformation. J Biol Chem 1969; 244: 1961-1967.

33. Wang YQ, Tang BP, Zhang HM, Zhou QH, Zhang GC. Studies on the interaction between imidacloprid and human serum albumin: spectroscopic approach. J Photochem Photobiol B 2009; 94: 183-190.

34. Seedher N, Agarwal P. Competitive binding of fluoroquinolone antibiotics and some other drugs to human serum albumin: a luminescence spectroscopic study. Luminescence 2013; 28: 562-568.

35. Seedher N, Agarwal P. Complexation of fluoroquinolone antibiotics with human serum albumin: a fluorescence quenching study. J Lumin 2010; 130: 1841-1848.

36. Xiao J, Chen L, Yang F, Liu C, Bai Y. Green, yellow and red emitting CdTe QDs decreased the affinities of apigenin and luteolin for human serum albumin in vitro. J Hazard Mater 2010; 182: 696-703.

37. Brunton L, Lazo J, Parker K. Goodman \& Gilman's The Pharmacological Basis of Therapeutics. 11th ed., New York, McGraw-Hill, 2005. 